DOI https://doi.org/10.18551/rjoas.2021-03.14

\title{
RATIO LEGIS REGULATION OF THE ESTABLISHMENT OF A JUDICIAL AGENCY SPECIFIC ELECTION OF REGIONAL HEAD IN INDONESIA
}

\author{
Firmanto Taufik*, Doctoral Candidate \\ Faculty of Law, University of Brawijaya, Malang \& STIH Muhammadiyah Bima, Indonesia
}

Fadli Moh., Professor

Safaat M. Ali, Istislam, Associates Professors

Faculty of Law, University of Brawijaya, Malang, Indonesia

*E-mail: taufik.f12@gmail.com

\begin{abstract}
This article results from legal research on exploring the ratio legis for forming a special judicial body for regional head elections in Indonesia. This study aims to find and find legal reasons for regulating the establishment of a special Regional head elections judiciary body in Indonesia. The method used in this research is normative legal research with several approaches, including conceptual approaches, statutory approaches, comparative approaches, and historical approaches. This research concludes that the ratio legis as a reason for the birth of the mandate for establishing a special judicial body in article 157 both in Law Number 8 of 2015 and in Law Number 10 of 2016 is not sufficient. The search for ratio legis, which should be the essence of the subject matter's philosophical content, which is why the emergence of the phrase "the form of a special judicial body," is not too well debated academically. The concept of 'special judicial bodies' emerged and surfaced in the Regional head elections Bill more like a consensus or a "form of compromise" when The Constitutional Court of the Republic of Indonesia and the Supreme Court of the Republic of Indonesia shifted their authority to handle election disputes. It was then that an alternative emerged to form a special judicial body and a form of "way out of the deadlock situation" and as an "exit strategy" after the Constitutional Court Ruling Number 97 / PUU-XI / 2013. From the 'form' aspect of this special judicial body, it is not sufficient to get an adequate portion of the discussion. There is no discussion about what form, jurisdiction, and how the special judicial body's operation mechanism is concerned. On the aspect of 'form', which is an important "origin of being", there was not enough academic study or discourse before its birth.
\end{abstract}

\section{KEY WORDS}

Ratio legis, establishment of a judicial agency specific, election of regional head, Indonesia.

Direct Regional Head Election in Indonesia is a strategic space for political contestation and local political participation to realize the people's interests in the regions. Direct Regional Head Election is a political process that is a political mechanism for electing leaders to fill positions in the regions democratically and a concrete manifestation of the actual implementation of regional autonomy or political decentralization. Direct regional head elections have become an integral part of the development of democratization in Indonesia. In the Indonesian constitutional perspective, direct Regional Head Election is one of the "biological children" of the 1998 Reform Movement as part of decentralization in the perspective of regional autonomy. Direct Regional Head Election is believed to be one of the panels to carry out political decentralization, allowing a shift/distribution of the epicenter of power from the center to the regions. In this case, the Regional Head Election is a "miniature election" which is a means of "reward and punishment" for choosing and/or changing the government regularly and periodically.

According to Ayuni, the implementation of direct regional head elections is believed to be a means of national integration by providing space for people to choose their own desired 
leader. It is a mechanism for selecting ideal leaders who come from the community in the area itself. Besides, direct regional head elections are also considered to accommodate an integrated selection system to produce qualified regional head candidates. Given the urgency of regional head elections, there has also been a growing enthusiasm for maintaining the spirit of local democracy and the quality of the process of holding regional head elections. In other words, implementing a good regional head election determines the quality of government and the success of democracy (Ayuni, 2018).

The constitutional mandate for holding regional head elections in Indonesia is stipulated in Article 18 paragraph (4) of the 1945 Constitution of the Republic of Indonesia, which states: "Governors, Regents, and Mayors respectively as Head of Provincial, Regency and City Government are elected democratically". If we look closely, the selection of the phrase "democratic" which is used to carry out the election, is different from the phrase "general election" as stipulated in Article 22E of the 1945 Constitution of the Republic of Indonesia, which regulates General Elections in Indonesia. However, post-reform, in Law Number 32 of 2004 concerning Regional Government, the phrase "democratically elected" is then translated to "directly elected by the people" by the legislators.

However, there is an intersection of constitutional norms that "smell contradictory" and may even trigger legal polemics. Article 22E of the 1945 Constitution, which regulates elections, does not include regional head elections, but regulations on regional head elections are included in the regional government division. So this raises the opinion that regional head elections are part of the Regional Government legal regime and not an election legal regime. Indeed, there is no difference between elections and regional head elections when viewed from the context of direct elections. Through the Decision of the Constitutional Court of the Republic of Indonesia Number 72-73 / PUU-II 2004 dated March 22,2005 , the Constitutional Court of the Republic of Indonesia has determined that regional head elections are elections. Therefore, the Constitutional Court of the Republic of Indonesia used the term 'regional head elections', which was accommodated in Law Number 12 of 2008.

Until now, the Constitutional Court of the Republic of Indonesia has for more than 12 years carried out its function and authority as a judicial body for disputes over the results of regional head elections. In its journey, the Constitutional Court of the Republic of Indonesia has produced quite dynamic, significant, and sometimes controversial developments (compared to the exercise of authority in resolving disputes over the Legislative and Presidential Elections). Junaidi stated that the Constitutional Court of the Republic of Indonesia had tried to fill this void by acting not only as a "Calculator Court" (Junaidi, 2013). The Court argues that the Constitutional Court of the Republic of Indonesia must uphold justice and maintain democracy in the regional head election process. If there are violations that injure democratic values and affect the results in the process, then the Constitutional Court of the Republic of Indonesia can examine the case. Despite the progressive controversy with all its consequences, the Constitutional Court of the Republic of Indonesia was once a hero of substantive rights.

However, on its way to exercising its authority to adjudicate disputes over the results of regional head elections, the Constitutional Court of the Republic of Indonesia once made a quite controversial decision, the Constitutional Court of the Republic of Indonesia annulled its authority to adjudicate disputes over the results of regional head elections. Through the decision on case Number 97 / PUU-XI / 2013, which tested Law Number 12 of 2008. It was overshadowed by 3 (three) constitutional judges who had dissenting opinions, namely Arief Hidayat, Anwar Usman, and Ahmad Fadil Sumadi. The Constitutional Court of the Republic of Indonesia ruled that the dispute over regional head elections results is not a limitation authority that falls under the Constitutional Court of the Republic of Indonesia as stipulated in the Constitution. In its consideration, the Court thinks:

"In understanding the authority of the Constitutional Court of the Republic of Indonesia as stipulated in Article 24C Paragraph (1) of the 1945 Constitution, we must again look at the meaning of the text, the original intent, the comprehensive grammatical meaning of the 1945 Constitution. Therefore, as described above. "General elections according to Article 22E of 
the 1945 Constitution must be interpreted in a limitative manner, namely general elections held to elect members of the DPR, DPD, President and Vice President as well as DPRD and held every five years".

In the conclusion of the Constitutional Court Decision of the Republic of Indonesia Number 97 / PUU-XI / 2013, the Court granted the Petitioners' petition in its entirety, in which the Constitutional Court of the Republic of Indonesia stated that Article 236C of Law Number 12 of 2008 contradicts the 1945 Constitution of the Republic of Indonesia, and has no binding legal force so that the Constitutional Court of the Republic of Indonesia is not authorized to adjudicate disputes over the results of regional head elections. However, in this decision, the Court also stated that the Constitutional Court of the Republic of Indonesia is still authorized to adjudicate disputes over regional head elections as long as there is no law regulating it.

The current condition is that disputes over the results of regional head elections will still be tried by the Constitutional Court, even though referring to the Constitutional Court decision Number 97 / PUU-XI / 2013 regional head elections are not included in the legal regime for elections, so the logical consequence is the settlement of disputes over the results of regional head elections is not the domain of the Constitutional Court's jurisdiction. However, as long as the special judiciary was not formed, the Constitutional Court was given a temporary mandate until the special judiciary body for regional head elections was formed.

The problem of "denial of the authority to judge" disputes over the results of regional heads by the Constitutional Court of the Republic of Indonesia through Decision Number 97 / PUU-XI / 2013 is getting more complex and more complicated after the issuance of Law Number 8 of 2015 in conjunction with Law Number 10 of 2016 which mandates 'Special Judicial Bodies' regional head election dispute. In Article 157 of Law Number 10 of 2016, it is determined:

- Cases of disputes over an Election's results shall be examined and tried by a special judicial body;

- As referred to in paragraph (1), the special judiciary shall be established before the implementation of the simultaneous national election;

- Cases of disputes over the determination of vote acquisition results of the Election shall be examined and tried by the Constitutional Court until establishing a special judicial body.

From this, the mandate to establish a "special judicial body" has not stopped the polemic. This article does not clearly define the form, institutionalization, and jurisdiction of the agency's authority. Likewise, the Elucidation section of this article only states, Article 157 is 'Self-explanatory'. This, of course, does not concretely explain the legislators' intent or background concerning the form and jurisdiction of the authority of the special judicial body. According to Indrati, the 'explanation' part should be an 'official interpretation' (authentic) of the legislators who can help determine the purpose or background of the formation of these laws and regulations (Indrati, 2007).

Meanwhile, about the time limit for forming a special judiciary "before the implementation of simultaneous national elections", there are also frequent changes in the arrangement. Initially, based on Article 201 paragraph (7) of Law Number 8 of 2015 'National Simultaneous Election', which became the time limit for forming a special judicial body, it was scheduled to occur in 2027. However, this provision changed along with the amendment of the Law, where Article 201 Paragraph (8) Law Number 10 of 2016 states: "National simultaneous voting in the Election of Governors, and Deputy Governors, Regents and Deputy Regents, as well as Mayors and Deputy Mayors throughout the territory of the Unitary State of the Republic of Indonesia, will be held in November 2024." The provisions in November 2024 are also likely to change according to the political constellation of Indonesian law.

Moving on from legal problems and non-legal problems in the form of polemics in the community, from here, it is crucial to trace the ratio legis article, Satjipto stated that ratio legis is the reason for the birth of legal regulations (Rahardjo, 2000). Ratio legis reflects the general concept of statutory regulation, and ratio legis is the essence of the law's philosophy. 
It can be a window to see the fundamental relevance of terms and arguments that are generally applied and binding value in forming laws.

From the background description, the problem formulation is how the ratio legis regulates the formation of a special judicial body for regional head elections in Indonesia?

\section{METHODS OF RESEARCH}

This research is the normative legal research to produce new arguments, theories, or concepts as a prescription (assessment) in the problem. In this study, several approaches were used, including conceptual approaches, statutory approaches, comparative approaches, and historical approaches (Marzuki, 2011). The technique of tracing legal materials in this research is literature study using content analysis. According to Valerine, content analysis in normative legal research refers to secondary data (literature), which provides mutual verification, correction, completion, and detailing. (Kriekhoff, 1995). Meanwhile, legal materials analysis is carried out by systematizing written legal materials that are descriptive, by describing the research results based on legal materials obtained, and then analyzing them. Qualitative analysis is then carried out by discussing the legal materials obtained by referring to the existing legal theory bases (Fajar \& Achmad, 2010).

\section{RESULTS AND DISCUSSION}

According to Dryda: "Thus, reflection over the general conceptual content of ratio legis may be a window through which practitioners could see the relevance of philosophizing about terms and arguments generally applied in legal practice" (Dryda, 2018). Furthermore, Kordela stated: "In the perspective of a legislator's axiological system, ratio legis may be qualified as a value, and also as a legally binding" (Marzena, 2018). Ratio legis is an important term in legal practice, ratio legis is the essence of the law's philosophy. It reflects the general concept of legislation, ratio legis can be a window in which practitioners can see the fundamental relevance of terms and arguments that are generally applied in legal practice. In the perspective of the legislator's axiological system, the legis ratio can qualify as a value and is also legally binding.

The choice of a 'Special Judiciary' to resolve disputes for regional head elections can be traced to the beginning of appearing in the Academic Manuscript of the Bill on Amendments to the Law on Regional Head Elections from the Ministry of Home Affairs of the Republic of Indonesia in 2016. The argument that the settlement of regional head election disputes is regulated in Article 18 Paragraph (4) in the 1945 Constitution of the Republic of Indonesia stipulates that "Governors, Regents, and Mayors respectively as heads of provincial, regency and municipal governments are elected democratically". From this, the Government as part of the Formation of Laws is of the view that the Election for Governors, Mayors and Regents is included in the Regional Government Regime and not the Election as stated in Article 22 E paragraph (2) of Constitution of the Republic of Indonesia which states: "General elections are held to elect members of the Council, People's Representatives, Regional Representative Council, President, and Vice President and Regional People's Representative Council ".

Furthermore, the argument was built that according to the provisions stipulated in Article 1 point 3 of Law Number 24 of 2003 concerning the Constitutional Court, that one of the petitions that can be submitted in writing to the Constitutional Court of the Republic of Indonesia is a dispute regarding the results of the General Election. Furthermore, Article 10 explains that the Constitutional Court of the Republic of Indonesia has the authority to judge at the first and last levels whose decisions are final, one of which is disputes over the General Election results. Referring to this provision, restrictively adjudicating disputes over the results of regional head elections is not the domain of the Constitutional Court of the Republic of Indonesia.

To resolve problems that arise later in the implementation of regional head elections, a special judiciary is needed to handle disputes over regional head elections or empower 
existing judicial institutions. The emergence of a special court's choice cannot be separated from the Constitutional Court Decision of the Republic of Indonesia Number 97 / PUU-XI / 2013 at that time, which implicated the Election mechanism for regional heads from the Election regime to the Regional Government. After these decisions, the legislators through Law Number 8 of 2015, in conjunction with Law Number 10 of 2016, mandated the establishment of a special court for regional head elections, which were under the Supreme Court's authority.

The holding of regional head elections simultaneously has a logical consequence, namely the emergence of regional head election disputes in many regions. The experience of holding regional head elections simultaneously has proven that the percentage of regional head election disputes has never subsided. There are more than $50 \%$ of regional head elections that file disputes to the Constitutional Court. Thus, it is inconceivable how many disputes over regional head elections will arise in the simultaneous regional head elections in 415 districts and 93 cities in 2024. Moreover, the simultaneous regional head elections will also be held simultaneously with the presidential and legislative elections. Quoting Wicaksono, the establishment of a special judicial body to handle regional head election disputes is a step that should be taken, considering the legal policy to hold regional head elections simultaneously in the future. Especially if you look deeper into the polarized handling of regional head election disputes to several judicial institutions today, it has created disharmony in decisions, injustice. It can result in resolving regional head election disputes that are not legally certain. (Nurhalimah, 2017).

$\mathrm{He}$ also added that at least it was evident from the Mataram State Administrative Court Decision Number 31 / G / 2010 / PTUN / MTR, which canceled the General Election Commission's decision on the determination of regional head candidates, but on the contrary in the Constitutional Court Decision of the Republic of Indonesia Number 186 / PHPU.D-VIII / 2010 assumes that the regional head election process is under the provisions, so that the determination of the candidate for the regional head is not canceled. (Nurhalimah, 2017). Likewise, the Regional Representative Council of the Republic of Indonesia records postconflict local election disputes in the administrative Court. Law does not provide room for the Regional General Election Commission to wait for the administrative Court's results in the implementation of the Regional Head Election stages. This means that the Regional General Election Commission When the State Administrative Court decided that the applicant (candidates/candidates) won. The respondent (Regional General Election Commission) lost, the Regional General Election Commission ignored the court's decision, the Regional Head Election process went according to schedule, and the applicant's victory was in vain, for example, Medan and Belitung East (DPD RI, 2010).

Disharmonization of the decisions caused by the segmented handling of regional head election disputes indicated the state to immediately form a Special Judiciary Body for regional head elections to accommodate substantive justice that is realized from the settlement of regional head election disputes with a comprehensive system (Nurhalimah, 2017). This is in line with Saragih who stated the importance of special election courts is also seen in the current conditions where there is weak law enforcement of election criminal offenses and overlapping laws and regulations between one another, which results in the problem of election crimes not being resolved properly (Saragih, 2017).

The birth of the choice of 'special judicial bodies' can also be traced from the discourse recorded in the text of the Minutes of the Working Meeting of the Commission II of the House of Representatives of the Republic of Indonesia Session Year 2014-2015 Session Period II with the Minister of Home Affairs, Minister of Law and Human Rights, and Committee I of the House of Representatives Regions of the Republic of Indonesia, on Friday, January 16, 2015, the agenda of the views of the factions and the Regional Representative Council of the Republic of Indonesia on the Government's statement on the Bill on the Stipulation of Government Regulations in place of Law Number 1 of 2014 concerning Election of Governors, Regents and Mayors into Law The Gerindra faction through Endro Hermono conveyed their views: 
"...Regional head elections are not included in the electoral regime, as well as in the ruling of the Constitutional Court of the Republic of Indonesia Number: 97 / PUU / VII / 2013, which has determined that the Constitutional Court of the Republic of Indonesia is not authorized to hear and decide cases of regional head elections, because regional head elections not included in the legal regime for elections. Whereas Article 18 paragraph (4) of the 1945 Constitution of the Republic of Indonesia, which has the spirit of a regional government regime, states that Governors, Regents, and Mayors are democratically elected, on the other hand, Article 22E paragraph (5) of the Constitution of the Republic of Indonesia Year 1945 stipulates that the General Election shall be held by a General Election Commission which is national, permanent and independent. At this point, the Gerindra Party faction sees that there will be legal problems in the future regarding the holding of regional head elections." (Hermono, 2014).

Regarding the implementation of regional head election disputes contained in Article 157 paragraph (1) of Government Regulation instead of Law Number 1 of 2014 states "that in the event of a dispute over the determination of the vote acquisition results of the election as a participant in the election, may submit a request for cancellation of the determination of the vote count results by the Election Commission. Provincial General Affairs and Regency / Municipal Election Commissions to the High Court appointed by the Supreme Court ". On the other hand, the Constitutional Court of the Republic of Indonesia is no longer authorized to adjudicate disputes over the results of regional head elections under the decisions passed some time ago. Meanwhile, the Supreme Court believes that it is better if the settlement of regional head election disputes is not in the Supreme Court but is handled by a Special Agency outside the court. Meanwhile, suppose the implementation of disputes, the regional head election is left to a special agency that is not centralized and has no experience in this matter. It can lead to different decisions because there are different interpretations of the same case (Hermono, 2014).

In the meeting, related to the dispute over the results of the regional head election of the Hanura Party, the view was that given the very short time in the election process, there were no other options. Simultaneously, the Hanura faction agreed that the Constitutional Court of the Republic of Indonesia could be appointed as the institution that would carry out the trial concerning disputes over results and disputes over regional head elections. However, if possible, slowly a special judicial institution should be established to handle the settlement of regional head election results disputes, because the Constitutional Court of the Republic of Indonesia, through its decision Number 97 / PUU / XI / 2013, has removed its authority to handle disputes over regional head election disputes, for this reason, it is very unconstitutional if the settlement of the results of regional head elections is still handled by the Constitutional Court of the Republic of Indonesia at a later date us continuously (Hutahuruk, 2014).

Meanwhile, the Golkar Party faction has the view that: "that the 1945 Constitution Article 24C paragraph (1) gives a mandate to the Constitutional Court of the Republic of Indonesia to resolve disputes over regional head elections, however, the Constitutional Court of the Republic of Indonesia issued decision Number 97 / PUU / VII / 2013 on May 9, 2014, which one of the decisions stated that regional head elections are not an election regime and therefore the Constitutional Court of the Republic of Indonesia has no authority to resolve disputes over regional head elections, but in the dictum of the decision of the Constitutional Court of the Republic of Indonesia in point 2 it explains that The Constitutional Court of the Republic of Indonesia has the authority to adjudicate disputes over the results of general elections, regional heads as long as there is no law that regulates this matter ". On this basis, the Golkar Party faction views that disputes over regional head elections should still be submitted to the Constitutional Court of the Republic of Indonesia, which is more prepared to handle regional head election disputes than the Supreme Court (Muchtar, 2014).

The United Development Party faction through H. MZ. Amirul Tamim expressed his view that a "special judicial body will handle the mechanism for resolving election disputes" but before it is formed, it will be handled by the Constitutional Court of the Republic of 
Indonesia as an institution that has been handling disputes over regional head elections (Tamim, 2014).

A similar view was conveyed by the Democratic Party Faction, which argued: "Another issue of constitutionality is the appointment of the Constitutional Court of the Republic of Indonesia as a substitute for the Supreme Court in examining and adjudicating disputes over the results of regional head elections. Even though the government eventually dissolved with its original stance that the dispute over the results of regional head elections became the domain of the Supreme Court, which in the end agreed to become the domain of the Constitutional Court of the Republic of Indonesia, for us in principle, the process of regional head election disputes must meet constitutional standards under duties and authorities of the branches of the judiciary. This is especially true if we believe that regional head elections are part of the regional government regime, not the electoral regime. Even so, the basic stance of the Democratic Party Faction does not question whether the settlement of disputes over the results of regional head elections is carried out at the Supreme Court or the Constitutional Court of the Republic of Indonesia. Still, the Supreme Court's appointment process to the Constitutional Court of the Republic of Indonesia is carried out through a consultation process both with the Supreme Court and the Constitutional Court. The Republic of Indonesia Democrat Party faction wants clarity first through an official statement at the Constitutional Court of the Republic of Indonesia, institutionally, its readiness to return to handling disputes over the results of the regional head elections in question, so that the principle of prudence and the principle of certainty in the drafting of this law can be obtained fulfill " (Utomo, 2014).

Another interesting opinion was conveyed by the spokesman for the National Awakening Party Faction, Abdul Malik Haramain, where regarding the settlement of disputes over regional head elections by the Constitutional Court, the National Awakening Party strongly agrees that the Constitutional Court of the Republic of Indonesia is the most competent, most authoritative, and fairest institution even if there was yesterday's incident because it was casuistic. Hopefully, the Constitutional Court will be firmer and more certain in the future and cleaner to resolve the dispute over regional head election disputes (Haramain, 2014).

While the National Mandate Party Faction has the view that the important issue in this bill is the settlement of regional head election disputes, the National Mandate Party faction has the view that until the formation of a regional head election dispute resolution judiciary within one year at the latest, before the simultaneous regional head elections are held. Nationally, regional head election disputes are handled by the Constitutional Court of the Republic of Indonesia with the existence of this special judicial body, the National Mandate Party Faction, hopes that regional head election disputes can be resolved fairly, so that regional head elections do not leave unfavorable accesses. Even tend to be detrimental. The fact shows that the cause of most regional head election disputes is the assumption of fraud in vote counting. To avoid the potential for fraud that occurs, the National Mandate Party Faction supports that recapitulation at the level of Voting Committees, Sub-districts, Villages is abolished. On the other hand, the recapitulation of votes from polling stations directly to the General Election Commission saves much more on the budget and also reduces the potential for tiered fraud and conflict (Sukiman, 2014).

Meanwhile, to explore the meaning of 'Special Judicial Bodies', it must be referred to the 1945 Constitution of the Republic of Indonesia as the Indonesian Constitution to divide this judicial power into five areas of justice, namely the General Court, the Religious Court, the State Administrative Court, the Military Court, and the Republican Constitutional Court Indonesia. As actors of judicial power, the Supreme Court of the Republic of Indonesia and the Constitutional Court of the Republic of Indonesia holds independent state power to administer the judiciary to uphold law and justice based on Pancasila and the 1945 Constitution of the Republic of Indonesia, for the sake of implementing the state law of the Republic of Indonesia.

According to Jimly, in the Indonesian context, the types and forms of judicial institutions in practice have indeed developed widely and are very diverse. Some judicial institutions or 
bodies are specifically developed within the scope of general justice, such as the Corruption Crime Court, Human Rights Court, Juvenile Court, Fishery Court, and Commercial Court. There are also special courts within the scope of State Administrative Courts, such as the Tax Court. Even in other fields, new ideas have emerged to form judicial bodies specializing in dealing with specific fields with good and noble aims to provide better guarantees to fulfill a sense of justice for the wider community. (Asshiddiqie, 2013).

Special Court has the authority to examine, hear, and decide certain cases that can only be established in one of the jurisdictions of a judicial body under the Republic of Indonesia's Supreme Court as regulated by law. Eight special courts currently exist, namely six courts within the General Courts' scope, one court within the State Administrative Court's scope, and one court within the scope of the Religious Courts. Specifically, the existing special court is "what is meant by 'special court', among others, is the Children's Court, Commercial Court, Human Rights Court, Corruption Crime Court, Industrial Relations Court and Fishery Court located within the General Court, as well as Tax Court located within the State Administrative Court. "

According to Gayus Lumbuun, the Indonesian judiciary's legal politics, which gave birth to several special courts, cannot be separated from the Supreme Court of the Republic of Indonesia's duties and roles. This thinking is based on several things, namely, first, juridically constitutional, the Supreme Court of the Republic of Indonesia is the highest judicial body, which is the national justice system's pinnacle. Second, specifically, each law on the formation of a special court has specific provisions regarding the relationship between the Supreme Court of the Republic of Indonesia and the special court, such as the special court judge's appointment and guidance (Lumbuun, 2013).

Meanwhile, Hamdan stated that the discourse regarding the existence and position of special courts in Indonesia is very important to be studied to be placed in the right position because special courts are one of the judicial system's sub-systems that exercise independent judicial powers. According to Hamdan, in general, there is no constitutional problem in the formation of a special court in Indonesia as long as it is placed in the existing judicial environment culminating in the Supreme Court. In constitutional science, the term open legal policy or optionally constitutional is known from the legislators informing law or establishing a state institution as long as it does not contradict or deviate from the constitution's provisions (Zoelva, 2013).

Notes regarding special judicial bodies' discourse do not merely highlight the Supreme Court of the Republic of Indonesia's duties and roles or its constitutional issues alone. In his study of this matter, Bedner examines the strategy of establishing special courts to improve judicial performance. He highlighted Indonesia's judiciary institutions, which continue to experience significant development, like a tidal wave. The Indonesian government, which changed regimes between 1950 and 1980, has created a new judiciary body and replaced the traditional courts that were abolished during the revolutionary period and after independence (Bedner, 2008).

According to Bedner, since the 1970s, ideas for reform have emerged, and the most prominent is to form a special judiciary, which is separate from the existing general justice system. However, Bedner also conveyed a critical note that the main task for a special judiciary's designers should focus on harmonizing competencies between the new judiciary and the existing courts. Another thing that must be considered is the practical conditions faced by judges. The limitation of competence to be too narrow (including limiting the competence to conduct judicial review), and too few cases to be handled, will leave judges vulnerable to conducting "shopping forums". Inadequate salaries of judges, the spread of corruption, and a lack of hierarchical control will strengthen the "shopping forums" process and ultimately lead to a situation where the courts are complicating matters rather than solving them. " (Bedner, 2012).

According to Jimly and the bodies that are expressly referred to as special judicial institutions, there are also new institutions established with semi- or quasi-judicial powers, such as the General Election Supervisory Board, the Honorary Council of General Election 
Administrators, the Information Commission. Central and Regional Information Commission, and the Commission for the Supervision of Business Competition (Asshiddiqie, 2013).

Theoretically, the specificity of a judicial body must be regulated by law. The ranks of judges are ad hoc in nature. Another characteristic of special courts is that procedural laws differ from one another. The purpose of a special court here is not a separate body that is separate from their respective spheres of justice. However, each judicial environment can form a special court, which is a chamber.

The formation of a special court is a form of legal politics and legal reality in Indonesia. This is because the formation of special courts is an effort to deal with the limitations of the existing judicial bodies by updating their structures with the ultimate goal of opening up access to justice for the public. But on the other hand, with the formation of a special court that can only be formed under one court environment, then each judicial institution's structure becomes wider. As a consequence of the Supreme Court of the Republic of Indonesia, which oversees the judiciary's four jurisdictions, the various courts are part of the judicial bodies under the Supreme Court of the Republic of Indonesia (Lumbuun, 2013).

The legal basis for the relationship between the Special Judiciary Body for regional head elections, which is a concern of this study, refers to Article 157 of Law Number 10 of 2016, which states: "For the time being, dispute resolution on regional head elections is still handled by the Constitutional Court of the Republic of Indonesia before the establishment of a special judicial body, to handle regional head election disputes ". From this clause, it must be interpreted that the settlement of disputes over the results of regional head elections must be resolved by a special court, which means that the settlement by the Constitutional Court of the Republic of Indonesia is currently only temporary, until the formation of a special court for regional head election disputes.

Hamdan stated that establishing a special judicial body for regional head elections is essential to ensure direct regional head elections, which are truly under democratic principles. Its implementation must be carried out with a system based on the principle of free and fair through a good and integrated system, among others: (1) the availability of material and formal legal framework that applies, is binding and serves as a guideline for organizers, contestants (pairs of candidates), and voters in carrying out their respective roles and functions, (2) the implementation of all activities or stages directly related to the implementation of regional head elections based on statutory provisions, (3) the integration of the electoral law enforcement process against the rules for regional head elections under the stages at each level, both those involving administrative, criminal, ethical and also disputes the result (Widodo, 2015).

In line with this, the Regional Head Election Law Number 8 of 2015, as amended by Law Number 10 of 2016, has regulated a dispute resolution mechanism. Article 157 mandates the establishment of a special court for the settlement of regional head election disputes. However, this Article is considered to have weaknesses because it does not further regulate, does not explicitly state the deadline for formation, which institution should form it, what the model is, and what jurisdictions have its powers. The article is also "incomplete" and only states, the special court must have been established before the national simultaneous regional head elections.

Provisions regarding the specificity of a judicial body that can only be formed in one of the judicial circles under the Supreme Court of the Republic of Indonesia are then affirmed in the form of norms of Article 27 paragraph (1) of Law Number 48 of 2009: "Special courts can only be formed in one of these environments judiciary that is under the Supreme Court as referred to in Article 25. "Meanwhile, the existing special court forms include Children's Court, Commercial Court, Human Rights Court, Corruption Crime Court, Industrial Relations Court, and Fishery Court located within the General Courts, as well as Tax Courts located within the Court. State Administration."

In connection with the uncertainty of the existence of a regional head election judiciary body, it is necessary to immediately decide which court specifically handles disputes over the results of regional head elections. This is due to the importance of adjustments and the preparation process in handling regional head election disputes, which are always difficult. 
So that in the special court, the regional head election will be ready to be used in the National Simultaneous Regional Head Election at a later date (Ayuni, 2018). This is important to immediately implement in realizing a democratic dignity that is and has legal certainty.

\section{CONCLUSION}

Ratio legis as the reason for the birth of the mandate for establishing a special judicial body in Article 157 both in Law Number 8 of 2015 and in Law Number 10 of 2016 is not sufficient. The search for ratio legis, which should be the essence of the philosophical content of the subject matter, which is the reason for the emergence of the phrase "the form of a special judicial body" are not too well debated academically. The concept of "special judicial bodies" emerged and emerged in the Regional Head Election Bill more as a consensus or a "form of compromise" when the Constitutional Court of the Republic of Indonesia and the Supreme Court of the Republic of Indonesia shifted their authority to handle regional head election disputes. It was then that an alternative emerged to form a special judicial body and a form of "way out of the deadlock situation" and as an "exit strategy" after the Constitutional Court decision of the Republic of Indonesia Number 97 / PUU-XI / 2013. From the 'form' aspect of this special judicial body, it is not sufficient to get an adequate portion of the discussion, and there is no discussion as to what form, jurisdiction, and how the mechanism of operation of the special judicial body is concerned. On the aspect of 'form', which is an important "origin of being", there was not enough academic study or discourse before its birth. In essence, the meaning of Special Judiciary Bodies can be explored by observing the nomenclature of "special judicial bodies" to examine and adjudicate cases of election result disputes so that conclusions can be drawn regarding dispute resolution institutions resulting from regional head elections, namely, a). a special judicial body, must be in the form of a 'judicial body' and not just a quasi-judicial institution; and b). special judicial bodies must be interpreted as a special judicial body under the Supreme Court of the Republic of Indonesia in Indonesia's judicial power system.

\section{REFERENCES}

1. Asshiddiqie, Jimly. (2013). Pengadilan Khusus. Dalam Hermansyah, (peny/eds). Putih Hitam Pengadilan Khusus. Jakarta: Sekretariat Jenderal KYRI, Cetakan Pertama.

2. Ayuni, Qurrata. (2018). Gagasan Pengadilan Khusus Untuk Sengketa Hasil Pemilhan Kepala Daerah, Jurnal Hukum \& Pembangunan 48 Nomor 1, Jakarta: Universitas Indonesia, 217-241. DOI: http://dx.doi.org/10.21143/.vol48.no1.1602

3. Bedner, Adriaan W. (2012). 'Shopping Forums': Pengadilan Tata Usaha Negara Indonesia, dalam Sulistyowati Irianto, et.al. Ed.1. Kajian Sosio-Legal (Denpasar: Pustaka Larasan; Jakarta: Universitas Indonesia, Universitas Leiden, Universitas Groningen.

4. Bedner, Adriaan W. (2008). Rebuilding The Judiciary In Indonesia: The Special Courts Strategy. Jurnal Yuridika Vol. 23 Nomor 3, September-Desember: 230-253.

5. Dian Agung Wicaksono dan Ola Anisa Ayutama, Inisiasi Pengadilan Khusus Pemilihan Kepala Daerah Dalam Menghadapi Keserentakan Pemilihan Gubernur, Bupati, Dan Walikota Di Indonesia, (Initiation of Special Court on the Local Election for Regional Leaders to Face the Simultaneously Election of Governor, Regent, and Mayor in Indonesia). Jurnal RechtsVinding, Vol. 4 No. 1, April 2015. DOI: http://dx.doi.org/10.33331/rechtsvinding.v4i1.53

6. Dryda, Adam. (2018). The Real Ratio Legis and Where to Find It. Verena Klappstein, Maciej Dybowski (Eds.), Ratio Legis: Philosophical and Theoretical Perspectives, Poland: Springer International Publishing.

7. Indrati, Maria Farida S. (2007). Ilmu Perundang-Undangan 2: Proses dan Teknik Pembentukannya. Yogyakarta: Kanisius.

8. Junaidi, Veri. (2013). Mahkamah Konstitusi Bukan Mahkamah Kalkulator. Depok: Themis Books. 
9. Keputusan Dewan Perwakilan Daerah Republik Indonesia Nomor 31/DPD RI/IV/20092010 Tentang Hasil Pengawasan Gelombang Ketiga Dewan Perwakilan Daerah Republik Indonesia Atas Penyelenggaraan Pemilihan Umum Kepala Daerah Secara Langsung Berdasarkan Undang-Undang Republik Indonesia Nomor 32 Tahun 2004 Tentang Pemerintahan Daerah Tahun 2010.

10. Kordela, Marzena. (2018). Ratio Legis as a Binding Legal Value, dalam Verena Klappstein, Maciej Dybowski (Eds), Ratio Legis: Philosophical and Theoretical Perspectives, Poland: Springer International Publishing.

11. Kriekhoff, Valerine J. L. (1995). Analisis Konten dalam Penelitian Hukum: Suatu Telaah Awal. Era Hukum: Jurnal IImiah IImu Hukum" Fakultas Hukum Universitas Tarumanagara, Nomor 6/Th.2/1995: 85-95.

12. Lumbuun, Gayus. (2013). Tantangan Pembaruan Pengadilan Khusus dalam Perspektif Mahkamah Agung. Dalam Hermansyah, (peny/eds). Putih Hitam Pengadilan Khusus. Jakarta: Sekretariat Jenderal KYRI, Cetakan Pertama.

13. Marzuki, Peter Mahmud (2011). Penelitian Hukum. Jakarta: Kencana Prenada Media Group.

14. Mukti Fajar ND dan Yulianto Achmad. (2010). Dualisme Penelitian Hukum Normatif \& Empiris. Yogyakarta: Pustaka Pelajar.

15. Nurhalimah, Siti. (2017). Pembentukan Badan Peradilan Khusus Pilkada, 'Adalah; Buletin Hukum dan Keadilan. Jakarta: Fakultas Syariah dan Hukum UIN Syarif Hidayatullah Volume 1 Nomor 5c: 25-26.

16. Rahardjo, Satjipto. (2000). Ilmu Hukum. Bandung: Citra Aditya Bakti.

17. Risalah Rapat Kerja KomisI II DPR RI Tahun Sidang 2014-2015 Masa Persidangan II dengan Menteri Dalam Negeri RI, Menteri Hukum dan HAM RI dan Komite I DPD RI, pada Jumat, 16 Januari 2015, dengan agenda Pandangan Fraksi-fraksi dan DPD RI terhadap keterangan Pemerintah atas RUU tentang Penetapan Perppu Nomor 1 Tahun 2014 tentang Pemilihan Gubernur, Bupati dan Walikota menjadi Undang-Undang.

18. Saragih, Andre Dosdy Ananta. (2017). Tinjauan Yuridis Pentingnya Pembentukan Peradilan Khusus Dalam Pemilu Serentak Menurut Undang-undang Pemilihan Kepala Daerah. Jurnal Lex et Societatis, Vol. V/Nomor3/Mei/2017: 167-175.

19. Widodo, Heru. (2015). Hukum Acara Perselisihan Hasil Pilkada Serentak, Jakarta: Sinar Grafika.

20. Zoelva, Hamdan. (2013). Problematika Penyelesaian Sengketa Hasil Pemilukada oleh Mahkamah Konstitusi. Jurnal Konstitusi, Volume 10, Nomor 3, September. DOI: https://doi.org/10.31078/jk\%25x. 